\title{
CAT25 defines microsatellite instability in colorectal cancer by high-resolution melting PCR
}

\author{
AG Sánchez, I Juaneda, HGI Eynard, AL Basquiera, E Palazzo, P Calafat, V \\ Palla, PA Romagnoli \& T Alvarellos
}

To cite this article: AG Sánchez, I Juaneda, HGI Eynard, AL Basquiera, E Palazzo, P Calafat, V Palla, PA Romagnoli \& T Alvarellos (2020): CAT25 defines microsatellite instability in colorectal cancer by high-resolution melting PCR, British Journal of Biomedical Science

To link to this article: https://doi.org/10.1080/09674845.2020.1730625

Accepted author version posted online: 17 Feb 2020.

Submit your article to this journal 지

山 Article views: 7

Q View related articles $₫$

View Crossmark data 
Publisher: Taylor \& Francis \& British Journal of Biomedical Science

Journal: British Journal of Biomedical Science

DOI: $10.1080 / 09674845.2020 .1730625$

CAT25 defines microsatellite instability in colorectal cancer by high-resolution melting PCR

AG Sánchez ${ }^{1,6}$, I Juaneda $^{2}$, HGI Eynard ${ }^{2}$, AL. Basquiera ${ }^{3}$, E Palazzo ${ }^{3}$, P Calafat ${ }^{4}$, V Palla ${ }^{4}$, PA. Romagnoli ${ }^{5,6}$, T Alvarellos $^{1,6}$

${ }^{1}$ Laboratorio de Biología Molecular e Histocompatibilidad, Hospital Privado

Universitario de Córdoba, Naciones Unidas 346, Córdoba 5016, Argentina.

${ }^{2}$ Servicio de Cirugía, Hospital Privado Universitario de Córdoba, Naciones Unidas 346, Córdoba 5016, Argentina.

${ }^{3}$ Servicio de Oncología, Hospital Privado Universitario de Córdoba, Naciones Unidas 346, Córdoba 5016, Argentina.

${ }^{4}$ Servicio de Anatomía Patológica, Hospital Privado Universitario de Córdoba, Naciones Unidas 346, Córdoba 5016, Argentina.

${ }^{5}$ Centro de Investigación en Medicina Traslacional Severo Amuchastegui (CIMETSA), Naciones Unidas 420, Córdoba 5016, Argentina.

${ }^{6}$ Instituto Universitario de Ciencias Biomédicas de Córdoba, Naciones Unidas 420, Córdoba 5016, Argentina.

Corresponding author: Ariel G. Sánchez, Hospital Privado Universitario de Córdoba, Naciones Unidas 346, 5016 Córdoba, Argentina. Tel: +549-(0)3514688839. Fax: +549-(0)351-4688276. E-mail: agsanchez78@outlook.com 
Keywords: CAT25-marker, Colorectal cancer, High-Resolution Melting, Microsatellite instability, Real-time PCR.

\section{Abstract}

Background: CAT25 ( $T_{25}$ mononucleotide repeat of the Caspase 2 gene), is a promising DNA marker for detecting microsatellite instability (MSI) in colorectal cancer. CAT25 has the potential to be incorporated into the Bethesda panel, a commonly used panel of DNA microsatellites, or replace it in its entirety. We aimed to develop and validate a high-resolution melting-PCR (HRM-PCR) method for CAT25 instability detection in clinical samples and study its allelic variation in our population.

Methods: The instability of CAT25, BAT25 (a poly(A) tract occurring in the $c-k i t$ gene) and BAT26 (a poly(A) tract localized in the $h M S H 2$ gene) microsatellites was assessed in DNA from tumour and peripheral blood obtained from 110 patients with colorectal cancer using HRM-PCR and capillary electrophoresis. Immunohistochemistry (IHC) staining for MSH2, MSH6, MLH1, and PMS2 enzymes was performed on tumours with high MSI. Allelic size variation of CAT25 was analyzed on peripheral blood DNA from 208 healthy volunteers.

Results: The HRM-PCR for CAT25 was validated in clinical samples. CAT25 showed a tight range of 64-66 base pairs. Of 110 tumours, 11 had high MSI, later confirmed by IHC. CAT25 defined MSI alone and when used together with BAT25 and BAT26. CAT25 results provided $100 \%$ predictive values and $p<0.0001$ to classify a tumour as having high MSI. 
Conclusions: We developed and validated a new HRM-PCR assay to detect CAT25 instability. Our findings showed a limited allelic size variation of CAT25 in the population and highlight CAT25 as a promising marker for MSI analysis.

\section{Introduction}

Microsatellites are sequences of repetitive DNA units ( 1 to 7 base pairs), and are likely sites of replication errors due to a failure of the DNA mismatch repair (MMR) system during DNA replication. These errors can be caused by either mutations or epigenetic modifications in the MMR genes resulting in microsatellite instability (MSI). The presence of MSI is indicated by the different number of base pairs of microsatellites from tumour DNA, with respect to the number of base pairs present in the normal DNA as can be found in peripheral blood cells. MSI screening is a well-established assay for defining Lynch syndrome (1). Individuals with this condition have a $50-70 \%$ lifetime risk of developing colorectal cancer and $40-60 \%$ of them are at risk of developing endometrial cancer and other malignancies (2). MSI status has also been proposed as a prognostic factor related to survival and is postulated as a predictive factor of response to the adjuvant therapy for patients with colorectal cancer $(3,4)$. Recent data have shown the importance of MSI testing for the selection of patients for immunotherapy using anti-PD-1/PD-L1 therapy (5).

The Bethesda panel is frequently used to assess the presence of MSI in colorectal cancer. The panel consists of two mononucleotides, BAT25 (a poly(A) tract occurring in $c-k i t$ ) and BAT26 (a poly(A) tract localized in $h M S H 2$ ) along with three dinucleotide markers (D17S250, D5S346, and D2S123) (6). However, this panel has limitations, since dinucleotide markers are less sensitive and specific for detecting tumours with mismatch repair deficiencies than mononucleotides. Due to 
this deficiency, only the use of mononucleotide markers was suggested for MSI testing (7). Furthermore, the use of mononucleotide microsatellites with limited allelic size variation could potentially avoid testing the corresponding normal DNA present in peripheral blood samples, often used as reference for MSI analysis (8)(9). In line with this, CAT25, a mononucleotide microsatellite with 25 repetitions of thymine located in the 3'untranslated region of the CASP2 gene has assessed for MSI testing (10). Moreover, different groups have demonstrated the usefulness of CAT25 in terms of clinical efficacy, suggesting that it is comparable to all the five microsatellites proposed in the Bethesda panel (10-13). The findings and needs described above highlight the importance of further studies of CAT25 in colorectal cancer. Here, we developed and validated a new HRM-PCR technique for CAT25 instability detection, which is usually performed using capillary electrophoresis technique. The HRM-PCR technique is a simpler and faster technique than capillary electrophoresis and has no problems with stutter bands as does capillary electrophoresis $(14,15)$. Another advantage is that in contrast to capillary electrophoresis, HRM-PCR works in a closed-system environment, which also reduces contamination risks with amplicons $(15)(16)$.

We present data supporting the use of CAT25 MSI testing, using colorectal tumours as a model, both alone and together with BAT25 and BAT26.

\section{Materials and methods}

One hundred and ten individuals (43 women / 67 men) with colorectal adenocarcinoma diagnosed by histopathological analysis and treated in our hospital were studied. The mean age was 66 years (range: $30-89$ ). The number and tumour location were 39 in the right colon, 36 in the left colon, 4 in the transverse colon, 11 
in rectosigmoid and 20 in the rectum. The cancers were classified according to The International Union Against Cancer (UICC)/American Joint Committee on Cancer (AJCC) guidelines as follows: 19, 33, 34, and 19 tumours recorded as stage I, II, III and IV respectively. Five tumours could not be classified by their stage. At diagnosis, 27 patients presented with metastases and in several of them, a carcinogenic involvement of more than one location was found. The number and anatomical sites affected by metastases were: 21 livers, 4 lungs, 2 bladders, 3 peritonea, 1 omentum, and 1 bone tissue. Before colorectal tumour removal surgery, there were 3 patients with rectal cancer who received neoadjuvant therapy with radiotherapy and chemotherapy (leucovorin and 5-fluorouracil). After colorectal surgery, adjuvant therapy was administered to 51 patients according to medical criteria (leucovorin, 5fluorouracil, capecitabine, irinotecan, oxaliplatin, bevacizumab using one drug or a combination of them). The average overall survival at 60 months after colorectal surgery was 43 months.

Five $\mathrm{mL}$ of peripheral blood and a piece of fresh tumour tissue were obtained from each patient. The CAT25 allelic pattern was determined using genomic DNA from peripheral blood (2.5mL) of 208 (104 women / 104 men) healthy volunteers (17). The study was approved by the Ethics Committee of the Hospital Privado Universitario de Cordoba and a written informed consent was obtained from all individuals.

Genomic DNA extraction was a follows. Genomic DNA from peripheral blood was extracted using MagNA Pure Compact Nucleic Acid Isolation Kit I following manufacturer's instructions (Roche applied science, Mannheim, Germany). This was also used to obtain Genomic DNA from fresh-frozen tumours as previously were performed by Xicola et al. (18) after a proteinase K (Promega, Madison WI, USA) 
digestion step $\left(2 \mathrm{mg} / \mathrm{mL}\right.$ overnight at $\left.56^{\circ} \mathrm{C}\right)$. Nucleic acid concentration was determined with an ultraviolet spectrophotometer (MaestroNano, MaestroGen Inc, Hsinchu City, Taiwan).

HRM-PCR conditions were as follows. The novel SmallCAT25 primers (Forward; 5'CTTCCCAACTTCCCTGTTCTTT-3' and Reverse; 5'-GGCGACAGAGCGAGACT-3') were generated from GenBank accession number NM_032982 using PrimerQuest software (Integrated DNA Technologies, Coralville, USA) (19). These primers were created to generate a small amplicon (65bp) and to avoid Alu sequences as suggested before (13). The procedure was carried out following criteria for HRMPCR setting (20). The reactions were carried out on HRM-compatible instruments: Eco Real-time PCR system (ECO) (Illumina, San Diego, USA) for technique validation, and Rotor-Gene 6000 (RG) (Qiagen, Hilden, Germany) and LightCycler Z480 (Z480) (Roche applied science, Mannheim, Germany) for the robustness assay (only for CAT25 analysis). HRM-PCR was accomplished in a total reaction volume of $10 \mu \mathrm{L}$ containing: $0.2 \mu \mathrm{L}$ of each SmallCAT25 primer (10 pmol/ $\mu \mathrm{L}), 5 \mu \mathrm{L}$ of Kapa HRM Fast master mix 2x (Kapa Biosystems, Wilmington, USA) $1.2 \mu \mathrm{L}$ of $\mathrm{MgCl} 225$ mM (Kapa Biosystems, Wilmington, USA), $1 \mu \mathrm{L}$ of DNA template $(25 \mathrm{ng} / \mu \mathrm{L})$ and 2.4 $\mu \mathrm{L}$ of water. The HRM-PCR cycling conditions were: $95^{\circ} \mathrm{C}$ for 3 minutes followed by 42 cycles of $95^{\circ} \mathrm{C}$ for 5 seconds and $64^{\circ} \mathrm{C}$ for 30 seconds. Before HRM step, the products were heated to $95^{\circ} \mathrm{C}$ for 10 seconds and cooled to $40^{\circ} \mathrm{C}$ for 5 seconds. Data for HRM analysis were collected within the range of 65 to $95^{\circ} \mathrm{C}$, rising at $0.1^{\circ} \mathrm{C} /$ second (RG and ECO instruments) or $0.02^{\circ} \mathrm{C} /$ second with 25 acquisitions/second (Z480). Procedure time (ECO instrument): 55 minutes. 
Validation parameters. Validation parameters for CAT25 HRM-PCR analysis were performed according to the guidelines for molecular genetics techniques as previously published (21).

Analytic sensibility and specificity determinations were as follows: measurements were calculated taking into consideration the capillary electrophoresis results. For evaluation of the template amount variation, DNA of Tumour 109/peripheral blood 109 (from the same patient) were added in triplicate to the reaction at different concentrations (10 ng, $25 \mathrm{ng}, 40 \mathrm{ng}$, and $80 \mathrm{ng}$ ). Additionally, we performed the HRM-PCR assay for CAT25 instability detection using DNA from 11 tumours with high MSI on three Real-time PCR instruments with HRM ability: ECO, RG, and Z480. Intra-run precision-repeatability: A single operator ran 10 replicates of the tumour DNA sample vs. 10 replicates of peripheral blood DNA from the same patient within the same run. These samples differed in one nucleotide length.

Inter-run precision-reproducibility (inter-run precision) was determined with the same samples used for previous tests, a single operator repeated the procedure on three different days. The samples were run in triplicate.

For HRM-PCR validation and testing of the allelic repeat pattern of CAT25, a fluorescent PCR-based assay followed by capillary electrophoresis analysis (ABI3730XL instrument, Applied Biosystems, Foster City, USA) was performed. To amplify the CAT25 marker, SmallCAT25 primers with the labelled (FAM) forward primer and the same cycling cited for HRM-PCR were used. Capillary electrophoresis assay was performed by Macrogen (Seoul, Korea). We used Peak Scanner Software 2 (Thermo Fisher Scientific, Waltham MA, USA) to estimate the amplicon size. Procedure time (approximate): 120 minutes. To amplify BAT25 and BAT26 markers, we used primers and PCR cycling as previously described (14). 
Forward primers were labelled with FAM (BAT25) and HEX (BAT26) fluorophores. Capillary electrophoresis analysis was performed following the same procedure as for CAT25.

Immunohistochemistry was performed on 9 biopsy samples classified as high MSI. Samples were fixed in $10 \% \mathrm{pH} 7$ buffered formaldehyde before being embedded in paraffin, and then 5 microns sections were made from selected blocks. The primary antibodies used were: MSH2 (CELL MARQUE, clone 6219-1129); MSH6 (CELL MARQUE, clone 44); MLH1 (Ventana, clone M1) and PMS2 (Ventana, clone ERP3947). The technique was carried out on Benchmark GX - VENTANA platforms (Roche, applied science, Mannheim, Germany) and revealed with Optiview DAB Detection Kit (Roche, applied science, Mannheim, Germany) in all cases. For the markings of MLH1 and PMS2, Optiview Amplification Kit (Roche, applied science, Mannheim, Germany) was also used according to protocols suggested by the manufacturer. Subsequently, the slides with the samples were dehydrated and mounted for visualization and evaluation under an optical microscope. A sample was considered negative when no tumour cell nucleus with positive staining for the protein under study (MSH2, MSH6, MLH1 or PMS2) was observed. Positive staining from the proteins studied observed in the cell nuclei of infiltrating lymphocytes, stromal cells and normal mucosa was considered as positive internal controls. CAT25, BAT25 or BAT26 instability was considered when a different amplicon size for each marker by capillary electrophoresis analysis was found comparing tumour DNA vs. peripheral blood DNA of the same patient. In HRM-PCR analysis, CAT25, BAT25 and BAT26 instability was considered to be present when HRM curves (Normalized and Different plot) were discordant between the samples previously described for capillary electrophoresis analysis. 
Tumour samples were considered to have high MSI when at least two of three mononucleotide markers (BAT25, BAT26, CAT25) showed instability by capillary electrophoresis analysis $(10,11,22)$. Predictive values and Fisher's exact test were calculated using GraphPad Prism 5 for Windows (GraphPad Software, Inc, San Diego, CA).

\section{Results}

CAT25 amplification using SmallCAT25 primers. According to the procedure described in materials and methods, the HRM-PCR for CAT25 MSI analysis generated only one specific product with an adequate cycle threshold (CT) for HRM analysis $(C T<30)$. The test reached $100 \%$ sensitivity and specificity for CAT25 since there was full concordance between the capillary electrophoresis and HRM-PCR results obtained with the analysis of 110 tumours and the paired peripheral blood from patients with colorectal cancer.

Different amounts of DNA template from a high MSI tumour/PB ranging from 10 to $80 \mathrm{ng} /$ reaction were studied. The 10 to $40 \mathrm{ng} /$ reaction range provided a better interpretation of HRM curves, so that $25 \mathrm{ng} /$ reaction was chosen for the following runs to be performed (Figure $1 \mathrm{~A}, \mathrm{~B}$ ). We found the same results for the 11 tumours with CAT25 instability in the three thermocyclers used. The reaction was reproducible in the intra-run precision-repeatability assay since the replicates grouped and melting profiles were equal for each sample in all 10 replicates (Figure $1 \mathrm{C}$, D). In addition, there was no misinterpretation of HRM curves when the same procedure was performed on different days (Inter-run precision-reproducibility assay).

CAT25, BAT25 and BAT26 instability and predictive values data is as follows. The results obtained by Capillary electrophoresis analysis confirmed the HRM-PCR 
outcomes and made it possible to distinguish the differences in bp between the study samples (Figure 2). Taking into account the results of the three microsatellite markers studied, 11 of the 110 tumours analyzed were classified as high MSI. The instability of the microsatellites analyzed by capillary electrophoresis, demonstrated the base pair shift, which in all cases was shown as shortening the length of the markers. The averages and standard deviations of these shifts in base pairs for each marker can be visualized in Table 1. The altered tumours displayed shifted HRM curves vs. those generated by PB from the same patient (Figure 2). Eleven samples from 110 colorectal tumour tissue presented allelic variation for CAT25, showing $100 \%$ positive predictive values (PPV) $(95 \% \mathrm{Cl}, 71.5$ to 100$)$ and negative predictive values (NPV) $(95 \% \mathrm{Cl}, 96.3$ to 100$)(p<0.001)$ for high MSI classification, using either HRM or capillary electrophoresis analysis.

Ten and 13 samples of the 110 cancers presented allelic variation for BAT25 and BAT26, respectively. One false positive for MSI-high classification was obtained for both BAT25 (tumour from patient 82) and BAT26 (tumour from patient 107) (Table 1). These data showed PPV for MSI testing of $92 \%$ for both. Two and no false negative were obtained for BAT25 (tumours from patients 35 and 64) and BAT26, respectively (Table 1). They also displayed NPV of $98 \%$ and $100 \%$, respectively. Allelic pattern analysis of CAT25. DNA samples from the healthy control group $(n=$ 208) and high MSI tumours $(n=11)$ were studied by capillary electrophoresis analysis using SmallCAT25 primers. This analysis showed a tight allelic range for CAT25: The control group data was mean [SD] 64.9 [0.55] bp, the patient data was $60.3[2.4] \mathrm{bp}(\mathrm{p}<0.01)$.

One of 11 tumours with high CAT25 MSI exhibited a major peak of $64 \mathrm{bp}$ in the electropherogram; this value is within the normal range, but the major peak in its 
corresponding peripheral blood was $66 \mathrm{bp}$, demonstrating allelic instability. The HRM analysis identified correctly this tumour sample as abnormal.

The immunohistochemistry (IHC) analysis was carried out in 9 of the 11 tumours with high MSI (Table 1). The PMS2 enzyme was absent in all samples and no expression of MLH1 was observed in 8/9, whereas MSH2 and MSH6 were expressed in all the tumours (Figure 3). All the cases analyzed by IHC correlated correctly with the results found in the microsatellite instability analysis (Table 1).

\section{Discussion}

MSI analysis is widely used in Lynch Syndrome screening, this being the most common cause of inherited colorectal cancer, accounting for $2 \%-4 \%$ of newly diagnosed cases and it is transmitted through an autosomal dominant pattern caused by germline mutations in the mismatch repair genes (23).

The suggested replacement of the dinucleotide microsatellites from Bethesda panel for mononucleotides in the MSI analysis (7), promotes the study of new microsatellites associated with Lynch Syndrome. Our data suggest that CAT25 appears as a very promising marker because it showed a limited allelic size variation in our population and besides, CAT25 could potentially give the same information alone as when used together with two additional markers from the Bethesda panel (BAT25 and BAT26). Moreover, CAT25 analysis can be carried out using a fast and simple technique such as HRM-PCR with certain advantages over capillary electrophoresis analysis, the most commonly used technique for MSI analysis.

Eleven of 110 tumour samples (10\%) had high MSI, in agreement with the range of 8 to $20 \%$ already reported in the literature (24). Each of these high MSI cases presented altered curves for CAT25 when analyzed with our novel and 
validated CAT25 HRM-PCR which also matched the results obtained with capillary electrophoresis analysis for CAT25. These findings together with the results from BAT25 and BAT26 in MSI testing from the same population reinforce the view that reducing the number of markers to be used from the Bethesda panel in the screening of Lynch Syndrome as proposed (4)(10)(11). Furthermore, fewer markers for MSI analysis provide the advantage of decreasing the costs and technical complexity while preserving the clinical applicability of the obtained results. CAT25 alone demonstrated the same clinical utility as using CAT25 together with BAT25 and BAT26 markers with optimal predictive values. Our findings are supported by previous literature using capillary electrophoresis analysis, where the sensitivity and specificity for microsatellite instability testing of CAT25 as a single marker were found to be the same as those detected when using five markers (BAT-25, BAT-26, MONO-27, NR-21, and NR-24) (25). However, it is known that HRM-PCR is faster and simpler than capillary electrophoresis and does not need post-PCR handling steps, therefore, reducing the harmful chance of contamination that can distort the results.

CAT25 is a genetic marker that may vary in size depending on the patient ethnicity (10). Although the study of allelic size variation for CAT25 has been carried out previously for other populations (10), there were no reports of CAT25 analysis for a population like ours. In our study, we observed a limited range of repetitions in the microsatellite marker CAT25 from the healthy volunteers group. These data enable CAT25 to be introduced to a more inclusive microsatellite instability panel that encompasses observations from different ethnic groups including the ones in our local population. 
The CAT25 HRM-PCR validation was performed in the ECO, but the other platforms could also be used to obtain excellent performance defining CAT25 instability in tumours, reinforcing the robustness of the technique. Taking into account that the technical characteristics vary, greater resolution capacity could be obtained when using the $\mathrm{Z} 480$. This platform allows obtaining 25 reading acquisitions per ${ }^{\circ} \mathrm{C}$ in the HRM step in contrast to the 10 reading acquisitions per ${ }^{\circ} \mathrm{C}$ offered by $E C O$ and $R G$, in addition to a more complete software platform to interpret the HRM results. IHC analysis customary for Lynch Syndrome found that MLH1 and PMS2 enzymes were absent while MSH2 and MSH6 were present in the tumours. The incorrect expression of the enzymes in the tumour tissue supports the lack of correction in the DNA replication errors, demonstrated by the shortening in the length of the microsatellites in the high MSI colorectal cancers.

Although CAT25 HRM-PCR possess all the mentioned advantages, we have found three limitations for this technique: 1- lack of multiplex format, if this was to be implemented, it could become a more simple and high-throughput assay; 2- The need of PB DNA that contains the normal allele required to contrast with the tumour DNA, for HRM analysis; and lastly, 3- the arguable limited application of our CAT25 HRM-PCR assay for paraffin-embedded tumour samples. The first two limitations are inherent to the HRM-PCR since it is an assay that is not characterized by easily adopting a multiplex format and usually a normal control is needed for the interpretation of its results, but they have the potential to be improved. On the third limitation, the validation of the assay for paraffin-embedded tissue will remain as a step to develop in the future. We believe all of these limitations can be solved through strategies such as those applied in analyzers like IdyllaTM MSI Assay (RUO) (Biocartis) that has a multiplex HRM-PCR format (7 novel markers), it can 
perform the study directly from paraffined-preserved tissue and does not require the analysis of paired normal tissue samples (26). However, the CAT25 analysis done by this new promising technology remains to be tested.

A clear caveat with our data is the small number of samples with high MSI. Nevertheless, this work represents an advance in biomedical science because it provides pilot validation of an assay for CAT25 instability detection using PCR-HRM in colorectal cancer and supports the potential for CAT25 as a marker in MSI analysis.

\section{Summary table}

What is known about this subject:

- MSI analysis is mainly used in Lynch Syndrome screening-management.

- New mononucleotide microsatellites with limited size allelic variation are encouraged for the replacement of dinucleotides of the Bethesda panel.

- CAT25 is a clinically effective MSI analysis (by capillary electrophoresis) in different ethnicities.

What this paper adds:

- CAT25 instability can be detected by a quick and simple technique such as PCR-HRM with certain advantages over capillary electrophoresis.

- CAT25 has limited size allelic variation.

- CAT25 has the potential to be a good marker in the testing of MSI in colorectal cancer.

\section{Acknowledgements}

The authors are grateful to Florencia Bonisconti (MS) for their assistance in editing this paper. 
2019-0255 approved by ADB $10^{\text {th }}$ February 2020

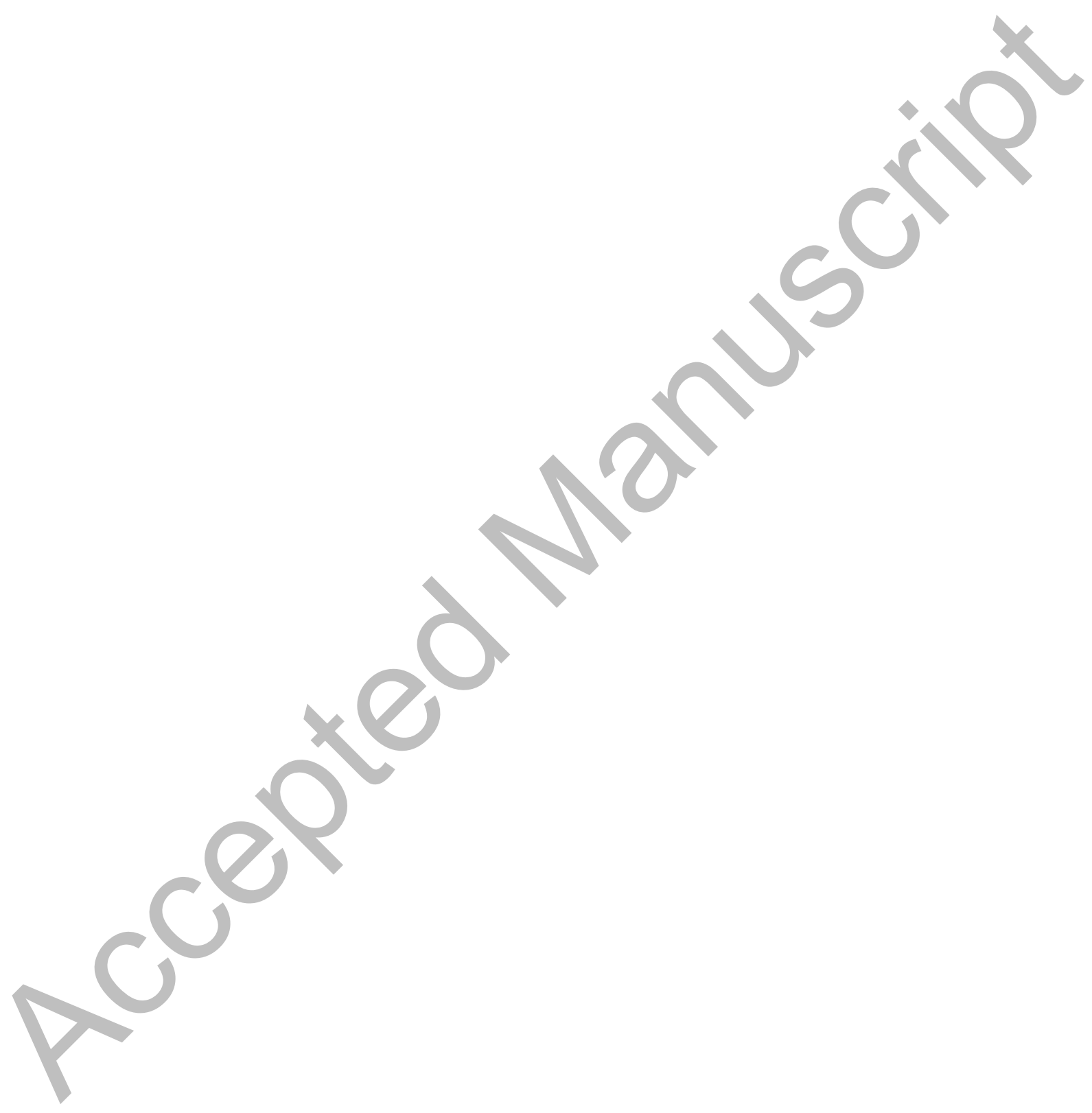




\section{References}

1. Lynch HT, de la Chapelle A. Genetic susceptibility to non-polyposis colorectal cancer. J Med Genet. 1999;36:801-18.

2. Sehgal R, Sheahan K, O'Connell PR, et al. Lynch syndrome: an updated review. Genes. 2014;5:497-507.

3. Sargent DJ, Marsoni S, Monges G, et al. Defective mismatch repair as a predictive marker for lack of efficacy of fluorouracil-based adjuvant therapy in colon cancer. J Clin Oncol. 2010;28:3219-26.

4. Tikidzhieva A, Benner A, Michel S, et al. Microsatellite instability and Beta2Microglobulin mutations as prognostic markers in colon cancer: results of the FOGT-4 trial. Br J Cancer. 2012;106:1239-45.

5. Sepulveda A, Hamilton S, Allegra C, et al. Molecular biomarkers for the evaluation of colorectal cancer: Guideline from The American Society for Clinical Pathology, College of American Pathologists, Association for Molecular Pathology, and the American Society of Clinical Oncology. J Clin Oncol. 2017; 35:1453-86.

6. Boland CR, Thibodeau SN, Hamilton SR, et al. A National Cancer Institute Workshop on Microsatellite Instability for Cancer Detection and Familial Predisposition : Development of International Criteria for the Determination of Microsatellite Instability in Colorectal Cancer. Cancer Res. 1998; 5:5248-57.

7. Umar A, Boland CR, Terdiman JP, et al. Revised Bethesda Guidelines for Hereditary Nonpolyposis Colorectal Cancer (Lynch Syndrome) and Microsatellite Instability. J Natl Cancer Inst. 2004; 96:261-8.

8. Murphy KM, Zhang S, Geiger T, et al. Comparison of the microsatellite instability analysis system and the Bethesda panel for the determination of microsatellite instability in colorectal cancers. J Mol Diagnostics. 2006; 8:30511.

9. Evrard C, Tachon G, Randrian V, et al. Microsatellite Instability: Diagnosis, Heterogeneity, Discordance, and Clinical Impact in Colorectal Cancer. Cancers (Basel). 2019;11:1-25.

10. Findeisen $\mathrm{P}, \mathrm{Kloor} \mathrm{M}$, Merx S, et al. T 25 Repeat in the 3' Untranslated Region of the CASP2 Gene : A Sensitive and Specific Marker for Microsatellite Instability in Colorectal Cancer. Cancer Res. 2005; 65:8072-8.

11. Bianchi F, Galizia E, Catalani R, et al. CAT25 Is a Mononucleotide Marker to Identify HNPCC Patients. J Mol Diagnostics. 2009; 11:248-52.

12. Pollack IF, Hamilton RL, Sobol RW, et al. Mismatch Repair Deficiency Is an Uncommon Mechanism of Alkylator Resistance in Pediatric Malignant Gliomas: A Report From the Children's Oncology Group. Pediatr Blood Cancer. 2011; 55:1066-71.

13. Morandi L, de Biase $\mathrm{D}$, Visani $\mathrm{M}$, et al. $\mathrm{T}([20])$ repeat in the 3 '-untranslated region of the MT1X gene: a marker with high sensitivity and specificity to detect microsatellite instability in colorectal cancer. Int J Colorectal Dis. 2012 May; 27:647-56.

14. Janavicius R, Matiukaite D, Jakubauskas A, et al. Microsatellite instability 
detection by high-resolution melting analysis. Clin Chem. 2010; 56:1750-7.

15. Susanti S, Fadhil W, Ebili HO, et al. N_LyST : a simple and rapid screening test for Lynch syndrome. J Clin Pathol. 2018;1-8.

16. Montgomery JL, Sanford LN, Wittwer CT, et al. High-resolution DNA melting analysis in clinical research and diagnostics. Expert Rev Mol Diagn. 2010;10:219-40.

17. Catelli M, Álvarez-Iglesias V, Gómez-Carballa A, et al. The impact of modern migrations on present-day multi-ethnic Argentina as recorded on the mitochondrial DNA genome. BMC Genet. 2011;12:77.

18. Xicola RM, Llor X, Pons E, et al. Performance of different microsatellite marker panels for detection of mismatch repair-deficient colorectal tumors. J Natl Cancer Inst. 2007;99:244-52.

19. Owczarzy R, Tataurov A V., Wu Y, et al. IDT SciTools: a suite for analysis and design of nucleic acid oligomers. Nucleic Acids Res. 2008;36:163-9.

20. Vossen RHAM, Aten E, Roos A, et al. High-resolution melting analysis (HRMA) - More than just sequence variant screening. Hum Mutat. 2009;30:860-6.

21. Norambuena PA, Copeland JA, Křenková P, et al. Diagnostic method validation: High resolution melting (HRM) of small amplicons genotyping for the most common variants in the MTHFR gene. Clin Biochem. 2009;42:130816.

22. Goeppert B, Roessler S, Renner M, et al. Mismatch repair deficiency is a rare but putative therapeutically relevant finding in non-liver fluke associated cholangiocarcinoma. Br J Cancer. 2019;120:109-14.

23. Kim JY, Byeon J-S. Genetic Counseling and Surveillance Focused on Lynch Syndrome. J Anus, Rectum Colon. 2019;3:60-8.

24. Vilar E, Gruber SB. Microsatellite instability in colorectal cancer-the stable evidence. Nat Rev Clin Oncol. 2010;7:153-62.

25. Babaei $\mathrm{H}$, Zeinalian M, Emami MH,et al. Simplified microsatellite instability detection protocol provides equivalent sensitivity to robust detection strategies in Lynch syndrome patients. Cancer Biol Med. 2017;14:142-50.

26. G. Maertens, B. De Craene, E. Rondelez, et al. Detection of microsatellite instability (MSI) in colorectal cancer samples with the automated Idylla MSI Test. Ann Oncol. 2017;28:2017-8. 
Table 1: Comparative results from Capillary electrophoresis, HRM curves and

\section{IHC analysis}

\begin{tabular}{|c|c|c|c|c|c|c|c|c|c|c|c|}
\hline \multirow[b]{2}{*}{ Patient } & \multicolumn{3}{|c|}{$\begin{array}{l}\text { CE bp tumor (bp } \\
\text { tumor - bp PB) }\end{array}$} & \multicolumn{3}{|c|}{$\begin{array}{l}\text { HRM curves (tumor } \\
\text { vs. PB) }\end{array}$} & \multicolumn{4}{|c|}{ Immunohistochemistry } & \multirow[b]{2}{*}{ MSI } \\
\hline & $\begin{array}{l}\text { CAT2 } \\
5\end{array}$ & BAT25 & BAT26 & CAT25 & BAT25 & BAT26 & $\begin{array}{c}\mathrm{MSH} \\
2\end{array}$ & $\begin{array}{c}\text { MSH } \\
6\end{array}$ & \begin{tabular}{|c|}
$\mathrm{MLH}$ \\
1 \\
\end{tabular} & \begin{tabular}{|c|} 
PMS \\
2
\end{tabular} & \\
\hline 35 & $\begin{array}{l}62(- \\
4)\end{array}$ & $\begin{array}{l}120 \\
(0)\end{array}$ & $\begin{array}{c}109(- \\
7)\end{array}$ & $\begin{array}{c}\text { instab } \\
\text { ility }\end{array}$ & $\begin{array}{l}\text { stabili } \\
\text { ty }\end{array}$ & $\begin{array}{l}\text { instab } \\
\text { ility }\end{array}$ & nd & nd & nd & nd & high \\
\hline 48 & $\begin{array}{l}58(- \\
8)\end{array}$ & $\begin{array}{l}115(- \\
5)\end{array}$ & $\begin{array}{l}105(- \\
9)\end{array}$ & $\begin{array}{c}\text { instab } \\
\text { ility }\end{array}$ & $\begin{array}{l}\text { instab } \\
\text { ility }\end{array}$ & $\begin{array}{l}\text { instab } \\
\text { ility }\end{array}$ & nd & nd & nd & nd & IIISII \\
\hline 55 & $\begin{array}{l}59(- \\
7)\end{array}$ & $\begin{array}{c}115(- \\
4)\end{array}$ & $\begin{array}{c}109(- \\
7)\end{array}$ & $\begin{array}{c}\text { instab } \\
\text { ility }\end{array}$ & $\begin{array}{l}\text { instab } \\
\text { ility }\end{array}$ & $\begin{array}{l}\text { instab } \\
\text { ility }\end{array}$ & $\begin{array}{l}\text { posit } \\
\text { ive }\end{array}$ & $\begin{array}{l}\text { posit } \\
\text { ive }\end{array}$ & $\begin{array}{c}\text { negat } \\
\text { ive }\end{array}$ & $\begin{array}{l}\text { negat } \\
\text { ive }\end{array}$ & high \\
\hline 64 & $\begin{array}{l}61(- \\
5)\end{array}$ & $\begin{array}{l}120 \\
(0)\end{array}$ & $\begin{array}{c}106(- \\
10)\end{array}$ & $\begin{array}{c}\text { instab } \\
\text { ility }\end{array}$ & $\begin{array}{l}\text { stabili } \\
\text { ty }\end{array}$ & $\begin{array}{l}\text { instab } \\
\text { ility }\end{array}$ & $\begin{array}{l}\text { posit } \\
\text { ive }\end{array}$ & $\begin{array}{l}\text { posit } \\
\text { ive }\end{array}$ & $\begin{array}{c}\text { negat } \\
\text { ive }\end{array}$ & $\begin{array}{c}\text { negat } \\
\text { ive }\end{array}$ & high \\
\hline 79 & $\begin{array}{c}63(- \\
3)\end{array}$ & $\begin{array}{c}116(- \\
3)\end{array}$ & $\begin{array}{c}106(- \\
8)\end{array}$ & $\begin{array}{c}\text { instab } \\
\text { ility }\end{array}$ & $\begin{array}{c}\text { instab } \\
\text { ility }\end{array}$ & $\begin{array}{c}\text { instab } \\
\text { ility }\end{array}$ & $\begin{array}{c}\text { posit } \\
\text { ive }\end{array}$ & $\begin{array}{l}\text { posit } \\
\text { ive }\end{array}$ & $\begin{array}{c}\text { negat } \\
\text { ive }\end{array}$ & $\begin{array}{c}\text { negat } \\
\text { ive }\end{array}$ & high \\
\hline 82 & $66(0)$ & $\begin{array}{c}107(- \\
13)\end{array}$ & $\begin{array}{l}116 \\
(0)\end{array}$ & $\begin{array}{c}\text { stabili } \\
\text { ty }\end{array}$ & $\begin{array}{l}\text { instab } \\
\text { ility }\end{array}$ & $\begin{array}{l}\text { stabili } \\
\text { ty }\end{array}$ & nd & nd & nd & nd & $\begin{array}{l}\text { non- } \\
\text { high }\end{array}$ \\
\hline 92 & $\begin{array}{l}64(- \\
2)\end{array}$ & $\begin{array}{c}114(- \\
5)\end{array}$ & $\begin{array}{c}109(- \\
6)\end{array}$ & $\begin{array}{c}\text { instab } \\
\text { ility }\end{array}$ & $\begin{array}{c}\text { instab } \\
\text { ility }\end{array}$ & $\begin{array}{l}\text { instab } \\
\text { ility }\end{array}$ & $\begin{array}{l}\text { posit } \\
\text { ive }\end{array}$ & $\begin{array}{l}\text { posit } \\
\text { ive }\end{array}$ & $\begin{array}{c}\text { negat } \\
\text { ive }\end{array}$ & $\begin{array}{c}\text { negat } \\
\text { ive }\end{array}$ & high \\
\hline 102 & $\begin{array}{c}58(- \\
8)\end{array}$ & $\begin{array}{c}109(- \\
10)\end{array}$ & $\begin{array}{c}104(- \\
11)\end{array}$ & $\begin{array}{c}\text { instab } \\
\text { ility }\end{array}$ & $\begin{array}{l}\text { instab } \\
\text { ility }\end{array}$ & $\begin{array}{c}\text { instab } \\
\text { ility }\end{array}$ & $\begin{array}{c}\text { posit } \\
\text { ive }\end{array}$ & $\begin{array}{l}\text { posit } \\
\text { ive }\end{array}$ & $\begin{array}{c}\text { positi } \\
\text { ve }\end{array}$ & $\begin{array}{c}\text { negat } \\
\text { ive }\end{array}$ & high \\
\hline 107 & $66(0)$ & $\begin{array}{l}119 \\
(0)\end{array}$ & $\begin{array}{c}104(- \\
9)\end{array}$ & $\begin{array}{c}\text { stabili } \\
\text { ty }\end{array}$ & $\begin{array}{c}\text { stabili } \\
\text { ty }\end{array}$ & $\begin{array}{c}\text { instab } \\
\text { ility }\end{array}$ & nd & nd & nd & nd & $\begin{array}{l}\text { non- } \\
\text { high }\end{array}$ \\
\hline 108 & $\begin{array}{l}57(- \\
9)\end{array}$ & $\begin{array}{c}113(- \\
7)\end{array}$ & $\begin{array}{c}103(- \\
12)\end{array}$ & $\begin{array}{l}\text { instab } \\
\text { ility }\end{array}$ & $\begin{array}{c}\text { instab } \\
\text { ility }\end{array}$ & $\begin{array}{c}\text { instab } \\
\text { ility }\end{array}$ & $\begin{array}{c}\text { posit } \\
\text { ive }\end{array}$ & $\begin{array}{l}\text { posit } \\
\text { ive }\end{array}$ & $\begin{array}{c}\text { negat } \\
\text { ive }\end{array}$ & $\begin{array}{c}\text { negat } \\
\text { ive }\end{array}$ & high \\
\hline 109 & $\begin{array}{c}65(- \\
1)\end{array}$ & $\begin{array}{c}113(- \\
6)\end{array}$ & $\begin{array}{c}106(- \\
9)\end{array}$ & \begin{tabular}{|c|} 
instab \\
ility
\end{tabular} & $\begin{array}{c}\text { instab } \\
\text { ility }\end{array}$ & $\begin{array}{c}\text { instab } \\
\text { ility }\end{array}$ & $\begin{array}{c}\text { posit } \\
\text { ive }\end{array}$ & $\begin{array}{l}\text { posit } \\
\text { ive }\end{array}$ & $\begin{array}{c}\text { negat } \\
\text { ive }\end{array}$ & $\begin{array}{c}\text { negat } \\
\text { ive }\end{array}$ & high \\
\hline 115 & $\begin{array}{c}62(- \\
4)\end{array}$ & $\begin{array}{l}111(- \\
10)\end{array}$ & $\begin{array}{c}109(- \\
6)\end{array}$ & $\begin{array}{c}\text { instab } \\
\text { ility }\end{array}$ & $\begin{array}{c}\text { instab } \\
\text { ility }\end{array}$ & $\begin{array}{c}\text { instab } \\
\text { ility }\end{array}$ & $\begin{array}{c}\text { posit } \\
\text { ive }\end{array}$ & $\begin{array}{l}\text { posit } \\
\text { ive }\end{array}$ & $\begin{array}{c}\text { negat } \\
\text { ive }\end{array}$ & $\begin{array}{c}\text { negat } \\
\text { ive }\end{array}$ & high \\
\hline 116 & $\begin{array}{c}58(- \\
7) \\
\end{array}$ & $\begin{array}{r}112(- \\
7)\end{array}$ & \begin{tabular}{|c|}
$107(-$ \\
$8)$ \\
\end{tabular} & $\begin{array}{c}\text { instab } \\
\text { ility }\end{array}$ & $\begin{array}{c}\text { instab } \\
\text { ility }\end{array}$ & \begin{tabular}{|c|} 
instab \\
ility \\
\end{tabular} & $\begin{array}{l}\text { posit } \\
\text { ive }\end{array}$ & $\begin{array}{l}\text { posit } \\
\text { ive }\end{array}$ & \begin{tabular}{|c} 
negat \\
ive
\end{tabular} & $\begin{array}{c}\text { negat } \\
\text { ive }\end{array}$ & high \\
\hline $\begin{array}{c}\text { Media bp (MSI } \\
\text { high only) }\end{array}$ & $\begin{array}{c}611 \\
5)\end{array}$ & $\begin{array}{c}113(- \\
5)\end{array}$ & $\begin{array}{c}107(- \\
8)\end{array}$ & & & & & & & & \\
\hline $\begin{array}{l}\text { Standard } \\
\text { deviation }\end{array}$ & $\begin{array}{c}2,8 \\
(2,7)\end{array}$ & $\begin{array}{c}3,5 \\
(3,4)\end{array}$ & $\begin{array}{c}2,2 \\
(2,0)\end{array}$ & & & & & & & & \\
\hline
\end{tabular}

CE: capillary electrophoresis; HRM: high resolution melting; IHC: Immunohistochemistry; MSI: microsatellite instability; PB: peripheral blood; bp: base pairs; nd: not determined. 
2019-0255 approved by ADB $10^{\text {th }}$ February 2020

\section{Figure legends}

Figure 1: Variation of the amount of DNA template. From a range of 10 to $80 \mathrm{ng}$ of DNA, 25 ng/reaction were chosen to conduct our study. (A) Normalized and (B) Difference plots HRM curves of CAT25 marker from DNA of a tumour with instability in CAT25 (T109) and peripheral blood (S109) from the same patient; both replicated three times.

Intra-assay reproducibility test for CAT25 marker. (C) Normalized and (D) Difference plots HRM curves from DNA of $\mathrm{MSI}(+)$ tumour vs. DNA from peripheral blood (PB) from the same patient; both replicated ten times. $\mathrm{MSI}(+)$ : tumour with instability in CAT25 marker proved by capillary electrophoresis. HRM: high resolution melting. 
2019-0255 approved by ADB $10^{\text {th }}$ February 2020

Figure 2: Comparative analysis between capillary electrophoresis and HRM techniques. Capillary electrophoresis shows a -8 bp shift between DNA of tumour T102 (A) vs. DNA of peripheral blood (PB) S102 (B) from the same patient, denoting CAT25 instability. (C) and (D) Shifted allele in the cited samples reflected by normalized and difference plot HRM curves, respectively. HRM: high resolution melting; bp: base pairs.
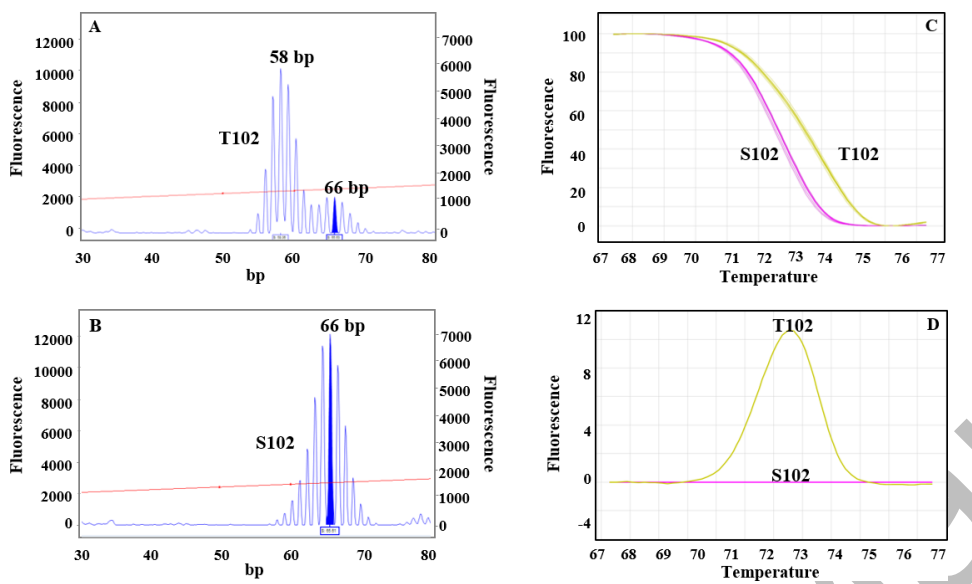
2019-0255 approved by ADB $10^{\text {th }}$ February 2020

Figure 3: Immunohistochemical analysis. A- MLH1 40x, loss of nuclear MLH1 immunoreactivity in tumour tissue with immunoreactive lymphocyte infiltrate. B- MSH2 40x, positive nuclear immunoreactivity in tumour tissue. C- MSH6 10x, positive nuclear immunoreactivity in tumour tissue. D- PMS2 40x, Loss of nuclear PMS2 immunoreactivity in tumour tissue with immunoreactive lymphocyte infiltrate. T: tumour; L: lymphocyte; SM: surgical margin 
2019-0255 approved by ADB $10^{\text {th }}$ February 2020 
2019-0255 approved by ADB $10^{\text {th }}$ February 2020 